\title{
Barriers in Health Information Systems and Technologies to Support Maternal and Neonatal Referrals at Primary Health Centers
}

\author{
Nabila Clydea Harahap, Putu Wuri Handayani, Achmad Nizar Hidayanto \\ Faculty of Computer Science, University of Indonesia, Depok, West Java, Indonesia
}

Objectives: This study explored health workers' perceptions and experiences regarding the maternal and neonatal referral system, focusing on barriers of health information systems and technologies (IS/IT) at primary health centers (PHCs) in South Tangerang, Indonesia. Methods: This qualitative study was conducted using semi-structured interviews, which were conducted at the South Tangerang District Health Office and three PHCs. Interviews were conducted with nine participants responsible for maternal and neonatal referrals in their organizations. The data were analyzed using qualitative content analysis. Results: In South Tangerang, the Primary Health Care Information System (SIMPUS) is used to register patients and record data on medical treatment. To facilitate referrals, the PHCs currently use the Integrated Referral Information System (SISRUTE), P-Care, and the Integrated Emergency Management System (SPGDT). The following four IS/IT barriers to support maternal and neonatal referrals were found: technology, human resources, organizational support, and the referral process and implementation. Conclusions: The barriers in technology, human resources, and organizational support cause problems in the maternal and neonatal referral process and in the implementation of referrals. Barriers to referrals can influence patients' ability to receive appropriate care in a timely fashion and lead to inefficiency in maternal and neonatal referrals. This study contributes knowledge about IS/IT implementation in maternal and neonatal referral systems and provides recommendations to health regulators and application developers for the implementation of IS/IT in Indonesia.

Keywords: Referral and Consultation, Health Information Systems, Primary Health Care, Maternal Health, Newborn Infant

Submitted: February 20, 2020

Revised: 1st, January 4, 2021; 2nd, January 28, 2021

Accepted: January 29, 2021

\section{Corresponding Author}

Nabila Clydea Harahap

Faculty of Computer Science, University of Indonesia, Kampus UI Depok, Pondok Cina, Kecamatan Beji, Kota Depok, Jawa Barat 16424, Indonesia. Tel: +62-85716526799, E-mail: nabila.clydea@ui.ac.id (https://orcid.org/0000-0001-7420-0396)

This is an Open Access article distributed under the terms of the Creative Commons Attribution Non-Commercial License (http://creativecommons.org/licenses/by$\mathrm{nc} / 4.0 /$ ) which permits unrestricted non-commercial use, distribution, and reproduction in any medium, provided the original work is properly cited.

(C) 2021 The Korean Society of Medical Informatics

\section{Introduction}

The referral system is an essential element of maternal and neonatal health [1]. Some developing countries have implemented health information systems or technologies (IS/IT) to support communication, transportation, or documentation in maternal and neonatal health referrals [2]. Previous studies about these technologies have primarily focused on design [3] and the benefits of IS/IT to support referrals [4,5]. However, there is a lack of research exploring users' perspectives on using technologies to support maternal and neonatal referrals.

The effective deployment of IS/IT requires both organizational support and users' ability to use technologies [6]. 
Unreliable infrastructure, lack of interoperability of systems, lack of regulations, and lack of healthcare workers' commitment are common barriers to IS/IT implementation in developing countries [7,8]. Barriers to IS/IT can cause inefficiency in maternal and neonatal referrals [2]. Discussing users' perspectives on current IS/IT use can determine future improvements for maternal and neonatal referral systems.

Limited research has been conducted on technologies to support maternal and neonatal referrals in Indonesia, which is a developing country. Moreover, research on the referral system in Indonesia still focuses on its implementation in hospitals, and little research has been conducted at primary health centers (PHCs) [9]. PHCs play an essential role as gatekeepers for curative and public health services [10] and link patients to Indonesia's referral system [11]. Some PHCs in districts/cities in Indonesia still process data manually [12], and there is rarely a designated person to manage health information systems [10]. The Indonesian government has developed IS/IT systems to support maternal and neonatal referral, such as the Information and Communication System for Maternal and Neonatal Referral Networks (SijariEMAS) and SMSBunda-a text messaging service for pregnant women and postnatal mothers [13]. However, these systems did not work effectively in several regions because they did not consider each region's specific characteristics [13].

The district of South Tangerang in Banten Province is an urban area in Indonesia that is currently developing an integrated referral system focusing on individual health referrals [14]. In Indonesia, maternal and neonatal referral health systems have different guidelines and requirements from those of individual health referrals [15]. This study explored health management and health workers' experiences with the maternal and neonatal referral system, focusing on IS/IT barriers at PHCs in South Tangerang.

\section{Case Description}

\section{Participant Selection}

The South Tangerang has 25 PHCs in seven sub-districts and one public hospital [16]. This study was conducted at three PHCs (Pamulang, Pondok Benda, and Pisangan) and the South Tangerang District Health Office (DHO) as the regulator of PHCs. These PHCs were selected based on a recommendation from the $\mathrm{DHO}$ and were considered to have exemplary IT implementation. This study used purposive sampling to select participants with the best knowledge concerning the research topic. The participants from the DHO worked in the family health section and the health human resources section, while the participants from the PHCs were workers in the maternal and child health section and administrative staff (Table 1).

\section{Data Collection}

The authors conducted semi-structured interviews between April and September 2019, with an average duration of 30-45 minutes. The interview questions were related to the maternal and neonatal referral process and health IS/IT that can support referrals (Table 2). Interviews were recorded and transcribed for analysis.

\section{Data Analysis}

This study used content analysis, consisting of decontextualization, recontextualization, categorization, and compilation [17] (Figure 1). In the decontextualization step, the authors read each transcribed text, broke the text into smaller mean-

Table 1. Participants' profile

\begin{tabular}{|c|c|c|c|c|c|}
\hline Code & Respondent's position & Experience & Education & Section & Organization \\
\hline $\mathrm{R} 1$ & Head of family health section & 10 years & Master's degree & Family health & South Tangerang DHO \\
\hline $\mathrm{R} 2$ & Staff of family health section & 14 years & Master's degree & Family health & South Tangerang DHO \\
\hline R3 & $\begin{array}{l}\text { Staff of health human } \\
\text { resource section }\end{array}$ & 7 years & Bachelor's degree & Health human resources & South Tangerang DHO \\
\hline $\mathrm{R} 4$ & Midwife & 5 months & Diploma & Maternal and child health & Pondok Benda PHC \\
\hline R5 & Admin & 7 years & Bachelor's degree & Administrative & Pondok Benda PHC \\
\hline R6 & Doctor & 5 years & Bachelor's degree & Maternal and child health & Pamulang PHC \\
\hline R7 & Midwife & 8 years & Diploma & Maternal and child health & Pamulang PHC \\
\hline $\mathrm{R} 8$ & Admin & 5 years & High school & Administrative & Pamulang PHC \\
\hline R9 & Midwife & 3 years & Diploma & Maternal and child health & Pisangan PHC \\
\hline
\end{tabular}

DHO: District Health Office, PHC: primary health center. 
Table 2. Interview questions

\begin{tabular}{|c|c|c|}
\hline & Interview questions in $\mathrm{DHO}$ & Interview questions in PHCs \\
\hline \multicolumn{3}{|c|}{ Maternal and neonatal referral process and implementation } \\
\hline Q1 & $\begin{array}{l}\text { What are the procedures for the maternal and neonatal } \\
\text { referral system implemented by South Tangerang DHO? } \\
\text { Is there a regional mapping and referral system flow? }\end{array}$ & $\begin{array}{l}\text { What are the procedures for the maternal and neonatal } \\
\text { referral system implemented in PHC? }\end{array}$ \\
\hline Q2 & $\begin{array}{l}\text { Does the South Tangerang DHO have a complete list of } \\
\text { healthcare facilities and their availability in the South } \\
\text { Tangerang area? }\end{array}$ & $\begin{array}{l}\text { Does the PHC have a complete list of healthcare facilities } \\
\text { and their availability in the South Tangerang area? }\end{array}$ \\
\hline Q3 & $\begin{array}{l}\text { How does South Tangerang DHO manage transporta- } \\
\text { tion in maternal and neonatal referrals in the South } \\
\text { Tangerang area? }\end{array}$ & $\begin{array}{l}\text { How does PHC manage transportation in maternal and } \\
\text { neonatal referrals in the South Tangerang area? }\end{array}$ \\
\hline Q4 & $\begin{array}{l}\text { How does South Tangerang DHO manage the communi- } \\
\text { cation or feedback on maternal and neonatal referrals in } \\
\text { the South Tangerang area? }\end{array}$ & $\begin{array}{l}\text { How does PHC manage the communication or feed- } \\
\text { back on maternal and neonatal referrals in the South } \\
\text { Tangerang area? }\end{array}$ \\
\hline Q5 & $\begin{array}{l}\text { How does the South Tangerang DHO monitor and evalu- } \\
\text { ate the maternal and neonatal referral systems in all } \\
\text { PHCs in the South Tangerang area? }\end{array}$ & $\begin{array}{l}\text { How does the PHC manage back-referral cases from } \\
\text { higher health facilities? }\end{array}$ \\
\hline Q6 & $\begin{array}{l}\text { How does the South Tangerang DHO conduct guidance } \\
\text { and supervision of referrals in all PHCs in the South } \\
\text { Tangerang area? }\end{array}$ & $\begin{array}{l}\text { How does PHC monitor and evaluate the implementation } \\
\text { of maternal and neonatal referrals? }\end{array}$ \\
\hline Q7 & $\begin{array}{l}\text { How does the South Tangerang DHO conduct the valida- } \\
\text { tion or checking of reporting data from all PHCs? }\end{array}$ & $\begin{array}{l}\text { How does the PHC report the data about maternal and } \\
\text { neonatal referral system to the South Tangerang DHO or } \\
\text { other related parties? }\end{array}$ \\
\hline Q8 & $\begin{array}{l}\text { What are some problems often experienced related to } \\
\text { maternal and neonatal referral? }\end{array}$ & $\begin{array}{l}\text { What are some problems often experienced related to } \\
\text { maternal and neonatal referral? }\end{array}$ \\
\hline \multicolumn{3}{|c|}{ Health information systems and technologies } \\
\hline Q9 & $\begin{array}{l}\text { What are health information systems and technologies } \\
\text { used by the South Tangerang DHO? Is there any health } \\
\text { information system related to maternal and neonatal } \\
\text { referral systems? }\end{array}$ & $\begin{array}{l}\text { What are health information systems and technologies } \\
\text { used by the PHC? Is there any health information system } \\
\text { related to maternal and neonatal referral systems? }\end{array}$ \\
\hline Q10 & $\begin{array}{l}\text { What problems are often experienced by the South } \\
\text { Tangerang DHO regarding the implementation of health } \\
\text { information systems and technologies? }\end{array}$ & $\begin{array}{l}\text { What problems are often experienced by the PHC regard- } \\
\text { ing the implementation of health information systems } \\
\text { and technologies? }\end{array}$ \\
\hline Q11 & $\begin{array}{l}\text { What are expectations regarding the implementation of } \\
\text { health information systems and technologies to support } \\
\text { maternal and neonatal referral? }\end{array}$ & $\begin{array}{l}\text { What are expectations regarding the implementation of } \\
\text { health information systems and technologies to support } \\
\text { maternal and neonatal referral? }\end{array}$ \\
\hline
\end{tabular}

DHO: District Health Office, PHC: primary health center.

ing units, and created codes inductively [17]. In recontextualization, the authors compared the original data by rereading the transcribed text and the list of meaning units to check whether there are unmarked texts to be included. In the categorization step, the authors identified the categories and sub-categories from the meaning units. Finally, the authors choose the appropriate meaning units presented in the running text as quotations [17]. The authors did not find new codes and themes after analyzing interview results from five participants. The remaining interview results confirmed the answers of the other participants. The first author conducted the analysis, while others reviewed the process and categorization to ensure its trustworthiness. 


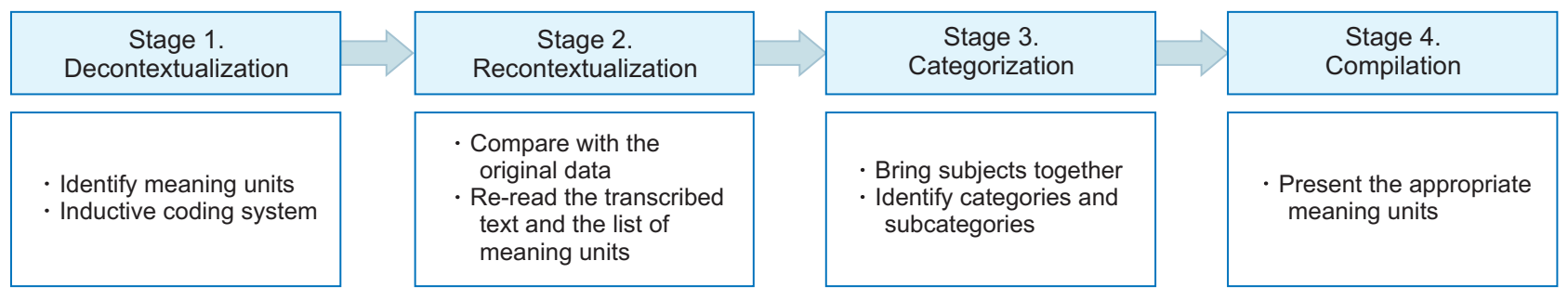

Figure 1. Qualitative content analysis process [17].

Table 3. Health information systems and technologies in South Tangerang PHCs

\begin{tabular}{clll}
\hline No & Name & \multicolumn{1}{c}{ Type } & \multicolumn{1}{c}{ Function(s) } \\
\hline 1 & SIMPUS & Web-based application & Register patients and record data on the medical treatment. \\
2 & SISRUTE & Web-based application & Manage general referral information exchange and communication. \\
3 & P-Care & Web-based application & Register patients, record diagnoses results and facilitate referrals for BPJS Kesehatan patients. \\
4 & SPGDT & Call center & Manage emergency cases. \\
\hline
\end{tabular}

PHC: primary health center, SIMPUS: Primary Health Care Information System, SISRUTE: Integrated Referral Information System, BPJS Kesehatan: Social Health Insurance Administration Body, SPGDT: Integrated Emergency Management System.

\section{Maternal and Neonatal Referral System in South Tangerang}

After a patient arrives at the maternal and child health section at a PHC, a health worker examines the patient. The health worker refers the patient to a hospital if complications are identified. The health worker communicates with the hospital to check available rooms and equipment and inform the hospital of the patient's condition. Furthermore, The health worker calls an ambulance for the patient, but the health worker also accompanies the patient in the ambulance.

In South Tangerang, the Primary Health Care Information System (SIMPUS) is used to register patients, record diagnoses, and report activities to the DHO [18]. For referral, PHCs use the Integrated Referral Information System (SISRUTE) for information exchange [19] and P-Care to generate referral letters for patients with coverage through the Social Health Insurance Administration Body (BPJS Kesehatan) [20]. SijariEMAS was replaced by one system, that is SPGDT (the Integrated Emergency Management System). SPGDT is the only emergency call center system in the South Tangerang area [21]. Table 3 presents the IS/IT used in South Tangerang.

\section{Results}

Barriers to IS/IT to support maternal and neonatal referrals consisted of technology, human resources, organizational support, and the referral process and implementation. Figure 2 illustrates the relationships between the barriers. Table

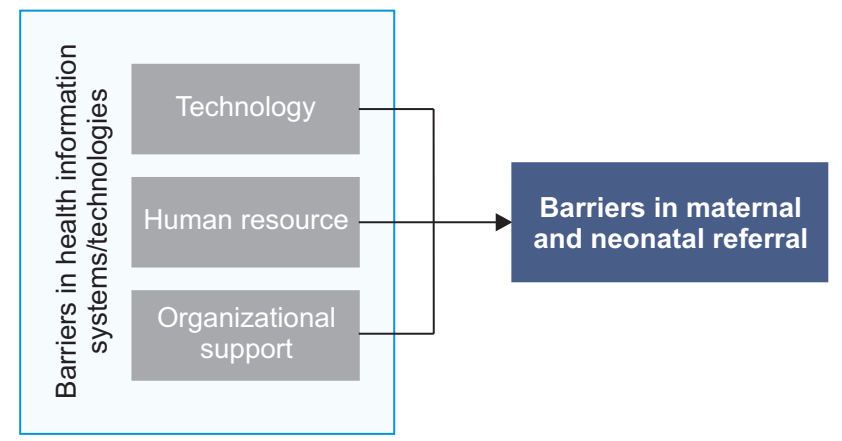

Figure 2. Barriers of health information systems and technologies to support maternal and neonatal referral.

4 describes each sub-category, with a selected quote for each barrier.

\section{1) Technology}

Due to the lack of IS/IT simplicity, the process of selecting hospitals is complicated for health workers. They can only refer patients to one hospital and must wait for a response before they make another referral. Delays in referral delivery and responses through this system make it difficult for health workers to refer patients quickly. Furthermore, the call center-based application (SPGDT) that is used nationally has a lack of availability during peak hours.

Existing applications cannot facilitate comprehensive referrals. One application can only serve one type of patient or referral. Another problem is the duplication of data work. For example, a health worker uses SIMPUS to record patient data during registration. When the patient needs to be re- 
Table 4. Summary of barriers in health information systems and technologies to support maternal and neonatal referrals at PHCs

\begin{tabular}{|c|c|c|c|}
\hline Category & Sub-category & Description & Quote \\
\hline \multirow[t]{6}{*}{ Technology } & $\begin{array}{l}\text { Lack of } \\
\text { simplicity }\end{array}$ & $\begin{array}{l}\text { Complex process of } \\
\text { selecting hospitals }\end{array}$ & $\begin{array}{l}\text { "One of the weaknesses of SISRUTE is that this application can only } \\
\text { refer to one hospital and we have to wait for a response before we } \\
\text { can make a referral to another hospital." [R6] }\end{array}$ \\
\hline & $\begin{array}{l}\text { Low respon- } \\
\text { siveness }\end{array}$ & $\begin{array}{l}\text { Slow system delivery } \\
\text { and response }\end{array}$ & $\begin{array}{l}\text { "There is SISRUTE, which is used with computers. Health workers } \\
\text { write the patient's name, complaints, chronology, and lab results, } \\
\text { then choose the hospital. Hospitals will get alarms from PHC } \\
\text { related to the referral. However, the problem is the slow response." } \\
\text { [R7] }\end{array}$ \\
\hline & $\begin{array}{l}\text { Lack of } \\
\text { availability }\end{array}$ & $\begin{array}{l}\text { The system is difficult } \\
\text { to access during peak } \\
\text { hours }\end{array}$ & $\begin{array}{l}\text { "We often had difficulty in making calls with SPGDT. Maybe this is } \\
\text { because many other users are using it." [R5] }\end{array}$ \\
\hline & $\begin{array}{l}\text { Lack of } \\
\text { comprehen- } \\
\text { siveness }\end{array}$ & $\begin{array}{l}\text { No system to support } \\
\text { the overall referral } \\
\text { process and referral } \\
\text { types }\end{array}$ & $\begin{array}{l}\text { "P-Care is only making referral forms. The system that provides } \\
\text { a response is SISRUTE. P-Care can be used for elective or non- } \\
\text { emergency referral cases. For emergency referral cases, we use } \\
\text { SISRUTE." [R6] }\end{array}$ \\
\hline & $\begin{array}{l}\text { Duplication of } \\
\text { data work }\end{array}$ & $\begin{array}{l}\text { Systems that have not } \\
\text { been integrated so } \\
\text { that health workers } \\
\text { must input the same } \\
\text { data in two different } \\
\text { systems }\end{array}$ & $\begin{array}{l}\text { "SIMPUS and SISRUTE are two different applications, so users } \\
\text { need to input data twice if they need to use both applications. } \\
\text { These applications are still not integrated." [R8] }\end{array}$ \\
\hline & $\begin{array}{l}\text { Poor internet } \\
\text { connection }\end{array}$ & $\begin{array}{l}\text { Slow internet connec- } \\
\text { tion and no backup } \\
\text { internet provider }\end{array}$ & $\begin{array}{l}\text { "The internet connection can be a problem. The organization that } \\
\text { provides the internet is only Kominfo. If the internet is down, we } \\
\text { do not have other backups." [R3] }\end{array}$ \\
\hline \multirow[t]{3}{*}{$\begin{array}{l}\text { Human } \\
\text { resources }\end{array}$} & $\begin{array}{l}\text { Lack of } \\
\text { readiness }\end{array}$ & $\begin{array}{l}\text { Resistance from health } \\
\text { workers and lack of } \\
\text { skill and knowledge } \\
\text { to use IT }\end{array}$ & $\begin{array}{l}\text { "The problem we are experiencing is the lack of readiness of health } \\
\text { workers in IT implementation. Many health workers are not yet } \\
\text { familiar with the use of applications." [R8] }\end{array}$ \\
\hline & $\begin{array}{l}\text { Increased } \\
\text { workload }\end{array}$ & $\begin{array}{l}\text { The use of systems in- } \\
\text { creases the workload } \\
\text { of health workers }\end{array}$ & $\begin{array}{l}\text { "We used to implement the SijariEMAS application. However, this } \\
\text { program was not run well, it increased our workload, and there } \\
\text { was too much data that had to be entered." [R5] }\end{array}$ \\
\hline & $\begin{array}{l}\text { Lack of human } \\
\text { resources }\end{array}$ & $\begin{array}{l}\text { Lack of health workers } \\
\text { to manage the system }\end{array}$ & $\begin{array}{l}\text { "SISRUTE can be used for emergency referrals. However, the prob- } \\
\text { lem is the lack of human resources, which would be fully respon- } \\
\text { sible and available to use the system. This lack of standby health } \\
\text { workers causes us to need a long time to receive a response." [R6] }\end{array}$ \\
\hline \multirow[t]{2}{*}{$\begin{array}{l}\text { Organizational } \\
\text { support }\end{array}$} & $\begin{array}{l}\text { Lack of } \\
\text { financial } \\
\text { support }\end{array}$ & $\begin{array}{l}\text { Lack of financial } \\
\text { support to ensure the } \\
\text { sustainability of IS/IT }\end{array}$ & $\begin{array}{l}\text { "We adopted SijariEMAS in } 2016 \text { with a little support from the } \\
\text { EMAS team. Moreover, assistance from the ministry of health is } \\
\text { less than one year. Previously, we had asked for support to extend } \\
\text { SijariEMAS for one more year. However, in the following year, the } \\
\text { support was eliminated." [R1] }\end{array}$ \\
\hline & $\begin{array}{l}\text { Lack of } \\
\text { policies }\end{array}$ & $\begin{array}{l}\text { Lack of policies to } \\
\text { include all parties } \\
\text { involved }\end{array}$ & $\begin{array}{l}\text { "In Tangerang district, all parties are involved because there are } \\
\text { policies that make the parties involved. It is expected that in the } \\
\text { future, there will be support from all parties or across sectors, for } \\
\text { example, from the infrastructure development sector, community, } \\
\text { or other social services." [R2] }\end{array}$ \\
\hline
\end{tabular}


Table 4. Continued 1

\begin{tabular}{|c|c|c|c|}
\hline Category & Sub-category & Description & Quote \\
\hline \multirow[t]{4}{*}{$\begin{array}{l}\text { Referral } \\
\text { process and } \\
\text { implementation }\end{array}$} & $\begin{array}{l}\text { Non-standard- } \\
\text { ized referral } \\
\text { communica- } \\
\text { tion }\end{array}$ & $\begin{array}{l}\text { The use of other com- } \\
\text { munication media } \\
\text { besides the IS/IT that } \\
\text { has been provided for } \\
\text { referral }\end{array}$ & $\begin{array}{l}\text { "For communication of emergency referral, we use SPGDT. How- } \\
\text { ever, sometimes, the response is not fast. So, many officers come } \\
\text { directly to the referral facility or use WhatsApp to find a referral } \\
\text { facility." [R2] }\end{array}$ \\
\hline & $\begin{array}{l}\text { Hospital tour- } \\
\text { ing }\end{array}$ & $\begin{array}{l}\text { Difficulties to find } \\
\text { health facilities that } \\
\text { have the required and } \\
\text { available facilities }\end{array}$ & $\begin{array}{l}\text { "It is hard to find a hospital because beds are often full, NICU } \\
\text { or ICU facilities are limited. There are } 29 \text { hospitals in South } \\
\text { Tangerang, there are quite a lot of facilities, but the beds are often } \\
\text { full, the NICU and ICU are limited, or there is a lack of isolation } \\
\text { space." [R1] }\end{array}$ \\
\hline & $\begin{array}{l}\text { Lack of follow- } \\
\text { up and back- } \\
\text { referral } \\
\text { mechanisms }\end{array}$ & $\begin{array}{l}\text { The process of follow- } \\
\text { ing up the patient's } \\
\text { condition and back } \\
\text { referrals is still done } \\
\text { using paper-based } \\
\text { forms }\end{array}$ & $\begin{array}{l}\text { "For referrals, most PHCs do not receive back-referrals from the } \\
\text { hospital, and there is no further information from the hospital. } \\
\text { This is also because PHCs do no following up on the patient's con- } \\
\text { dition." [R2] }\end{array}$ \\
\hline & $\begin{array}{l}\text { Lack of referral } \\
\text { success moni- } \\
\text { toring }\end{array}$ & $\begin{array}{l}\text { Lack of analysis regard- } \\
\text { ing the success of the } \\
\text { referral }\end{array}$ & $\begin{array}{l}\text { "In our current health information systems, there is no dashboard } \\
\text { for referral trends. For example, which facilities are most often } \\
\text { referred to, and what kind of diseases patients are most often } \\
\text { referred for." [R3] }\end{array}$ \\
\hline
\end{tabular}

PHC: primary health center, SISRUTE: Integrated Referral Information System, SPGDT: Integrated Emergency Management System, SIMPUS: Primary Health Care Information System, Kominfo: Ministry of Communications and Information, SijariEMAS: Information and Communication System for Maternal and Neonatal Referral Networks, EMAS: Expanding Maternal and Neonatal Survival, NICU: neonatal intensive care unit, ICU: intensive care unit.
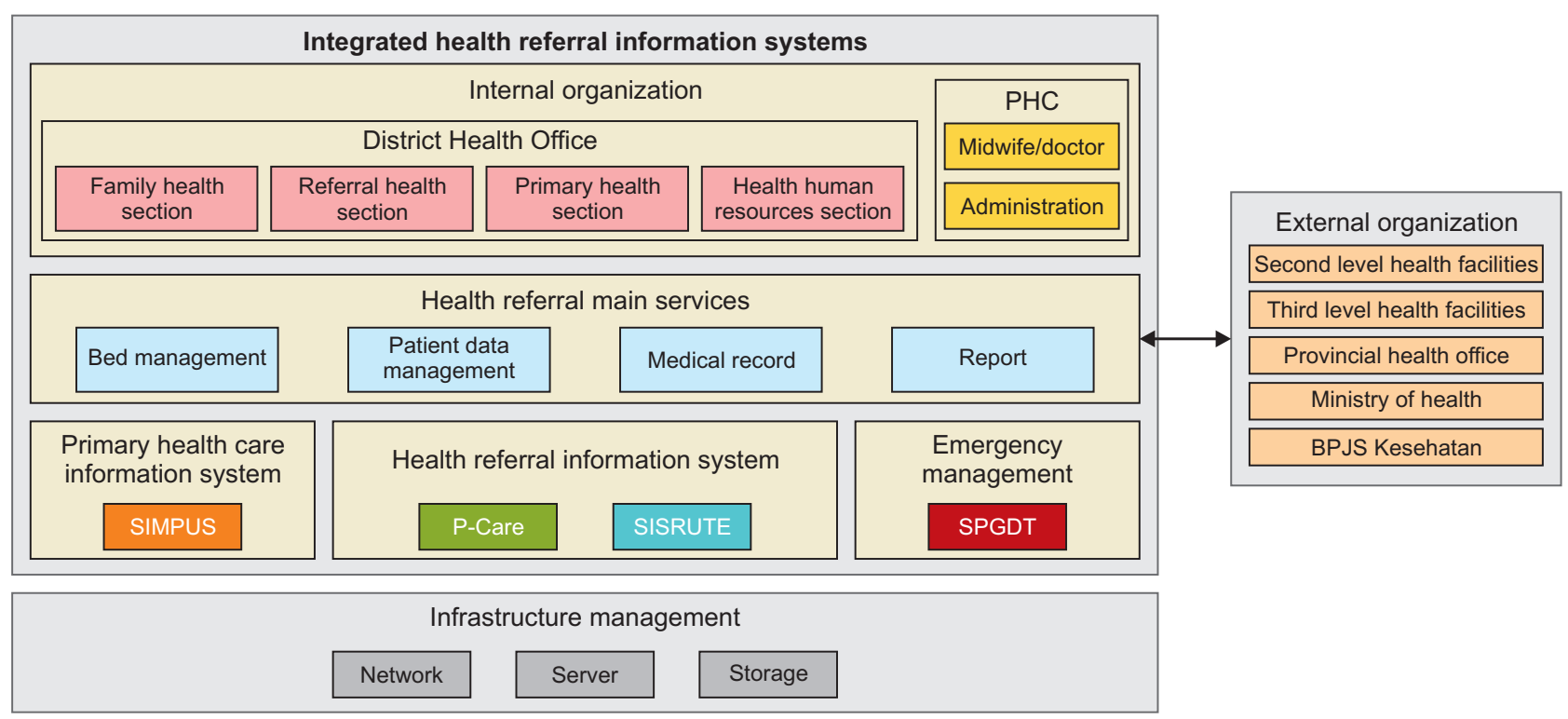

Figure 3. Architectural design of integrated health referral information systems. PHC: primary health centers, SIMPUS: Primary Health Care Information System, SISRUTE: Integrated Referral Information System, SPGDT: Integrated Emergency Management System, BPJS Kesehatan: Social Health Insurance Administration Body. 
ferred, the health worker must re-enter the patient's data in SISRUTE. Moreover, all respondents reported poor internet connections. The internet is only provided by the Ministry of Communications and Information (Kominfo), and there is no backup Internet provider.

\section{2) Human resources}

Health workers are not fully ready to use IS/IT due to their lack of IT knowledge or skills. Some applications can also increase their workload due to the need to input an excessive amount of data. Another problem is the lack of human resources to manage IS/IT who can be available at any time, especially to handle emergency referrals that need an immediate response.

\section{3) Organizational support}

A lack of financial support is one of the reasons why South Tangerang no longer uses SijariEMAS. Financial support is needed to perform server maintenance and training for health workers. Furthermore, a respondent at the DHO suggested that the lack of user involvement with SijariEMAS in South Tangerang stemmed from the absence of policies to involve all relevant stakeholders in the maternal and neonatal referral system.

\section{4) Referral process and implementation}

As a result of the above-mentioned IS/IT problems, health workers prefer using other communication media to refer patients or guiding patients and accompanying them to the preferred referral facility. Another problem is "hospital touring," because IS/IT cannot help health workers to see hospitals' capacity and make direct referrals to hospitals capable of admitting the patient. After referral, the hospital can return the patient to the PHC to continue treatment. However, this process is still done manually with a paper-based form. Moreover, there is no dashboard in the existing applications to see referral trends, such as the most referred health facilities and diseases, resulting in a lack of referral monitoring in this area.

\section{Discussion}

Functioning and available communication media make a significant contribution to referrals [22,23]. Applications that manage emergency cases should have a simple design even for non-computer-literate users [24]. IS/IT design should also facilitate referral comprehensively and consider all the characteristics of referrals [11]. In Indonesia, application developers often neglect existing IS/IT, which causes a lack of integration [25]. Enterprise architecture [14] and application programming interfaces [25] can serve as solutions to design integrated IS/IT. We proposed an architectural design for integrated health referral IS/IT in PHCs (Figure 3). To overcome internet problems, IS/IT should have the ability to work online and offline, with appropriate syncing $[7,8]$. The mobile internet, which offers more reliable connectivity, can also be considered [8].

Human resources problems could be caused by the lack of health workers' involvement in IS/IT development, which causes the technical requirements not to match their needs [25]. Training of human resources at all levels should be considered when implementing IS/IT [26]. Moreover, regulations in Indonesia should support IT personnel's needs at PHCs [18]. Appropriate regulations are also needed to strengthen information flow across institutions [8]. Appropriate financial investment levels for IS/IT implementation should also be determined to ensure continuity [26].

This study contributes knowledge about IS/IT implementation in maternal and neonatal referral systems and provides recommendations for health regulators and application developers to implement IS/IT in Indonesia. Applications must consider the needs and capabilities of health workers and the infrastructure conditions. IS/IT policies should include all technological and social aspects and provide sufficient investments to ensure IS/IT continuity. As a limitation, the sample size of this study was small and it only focused on South Tangerang. Therefore, the results may apply only to this local area and not be generalizable to other settings. Future research should analyze IS/IT barriers from different perspectives and explore how IS/IT influences mothers' and their families' acceptance of referrals.

\section{Conflict of Interest}

No potential conflict of interest relevant to this article was reported.

\section{Acknowledgments}

This work is a part of a master's degree thesis of Nabila Clydea Harahap, Faculty of Computer Science, University of Indonesia.

We certify that this work is supported by Pendidikan Magister Menuju Doktor untuk Sarjana Unggul (PMDSU) grant Ministry of Research, Technology, and Higher Education (Contract No. NKB-3031/UN2.R3.1.HKP.05.00/2019). 
The participant selection was conducted based on the letter of permission from the South Tangerang District Health Office (No. 070/1304/SDMK and 070/2206/SDMK).

\section{ORCID}

Nabila Clydea Harahap (https://orcid.org/0000-0001-7420-0396)

Putu Wuri Handayani (https://orcid.org/0000-0001-5341-3800)

Achmad Nizar Hidayanto (https://orcid.org/0000-0002-5793-9460)

\section{References}

1. Murray SF, Pearson SC. Maternity referral systems in developing countries: current knowledge and future research needs. Soc Sci Med 2006;62(9):2205-15.

2. Harahap NC, Handayani PW, Hidayanto AN. Barriers and technologies of maternal and neonatal referral system in developing countries: a narrative review. Informatics in Medicine Unlocked 2019;15:100184.

3. Gance-Cleveland B, Leiferman J, Aldrich H, Nodine P, Anderson J, Nacht A, et al. Using the technology acceptance model to develop StartSmart: mHealth for screening, brief intervention, and referral for risk and protective factors in pregnancy. J Midwifery Womens Health 2019;64(5):630-40.

4. Battle JD, Farrow L, Tibaijuka J, Mitchell M. mHealth for Safer Deliveries: a mixed methods evaluation of the effect of an integrated mobile health intervention on maternal care utilization. Healthc (Amst) 2015;3(4):1804.

5. Martinez B, Ixen EC, Hall-Clifford R, Juarez M, Miller AC, Francis A, et al. mHealth intervention to improve the continuum of maternal and perinatal care in rural Guatemala: a pragmatic, randomized controlled feasibility trial. Reprod Health 2018;15(1):120.

6. Walsham G. Health information systems in developing countries: some reflections on information for action. Inf Technol Dev 2020;26(1):194-200.

7. Jawhari B, Keenan L, Zakus D, Ludwick D, Isaac A, Saleh A, et al. Barriers and facilitators to Electronic Medical Record (EMR) use in an urban slum. Int J Med Inform 2016;94:246-54.

8. Sahay S, Nielsen P, Latifov M. Grand challenges of public health: How can health information systems support facing them? Health Policy Technol 2018;7(1):81-7.

9. Handayani PW, Pinem AA, Azzahro F, Hidayanto AN, Ayuningtyas D. The information system/information technology (IS/IT) practices in the Indonesia health re- ferral system. Inform Med Unlocked 2019;17:100263.

10. Mahendradhata $Y$, Trisnantoro L, Listyadewi S, Soewondo P, Marthias T, Harimurti P, et al. The Republic of Indonesia health system review. Geneva, Switzerland: World Health Organization; 2017.

11. Jahn A, De Brouwere V. Referral in pregnancy and childbirth: concepts and strategies. Safe motherhood strategies: a review of the evidence. Stud HSO\&P 2001; 17:225-42.

12. Minister of Health of the Republic of Indonesia. Workshop Integrasi SIKDA Generik versi 1.4, P-Care [Internet]. Jakarta, Indonesia: Minister of Health of the Republic of Indonesia; 2017 [cited at 2021 Apr 10]. Available from: https://pusdatin.kemkes.go.id/article/ view/17073100001/workshop-integrasi-sikda-generikversi-1-4---p-care.html.

13. Sofiah, Habsari SK, Sumardiyono. The effectiveness and perception of ICT program implementation in enhancing maternal and newborn survival among pregnant women in Indonesian society. Proceedings of the 3rd International Conference on Social and Political Science; 2016 Nov 2-3; Central Java, Indonesia. p. 160-9.

14. Handayani PW, Pinem AA, Munajat Q, Azzahro F, Hidayanto AN, Ayuningtyas D, et al. Health referral enterprise architecture design in Indonesia. Healthc Inform Res 2019;25(1):3-11.

15. Minister of Health of the Republic of Indonesia. Regulation of the Minister of Health of the Republic of Indonesia Number 97 of 2014 concerning health services before pregnancy, pregnancy, childbirth, and postpartum, contraceptive services and sexual health services [Internet]. Jakarta, Indonesia: Minister of Health of the Republic of Indonesia; 2014 [cited at 2021 Apr 10]. Available from: https://www.kebijakanaidsindonesia.net/id/dokumen-kebijakan?task=download. send \&id $=644 \&$ catid $=17 \& \mathrm{~m}=0$.

16. South Tangerang District Health Office [Internet]. Kota Tangerang Selatan, Indonesia: South Tangerang District Health Office; c2017 [cited at 2021 Apr 10]. Available from: https://dinkes.tangerangselatankota.go.id/.

17. Bengtsson M. How to plan and perform a qualitative study using content analysis. NursingPlus Open 2016;2: 8-14.

18. Afrizal SH, Handayani PW, Hidayanto AN, Eryando T, Budiharsana M, Martha E. Barriers and challenges to Primary Health Care Information System (PHCIS) adoption from health management perspective: a qualitative study. Inform Med Unlocked 2019;17:100198. 
19. Minister of Health of the Republic of Indonesia. Implementasi E-Health di Indonesia [Internet]. Jakarta, Indonesia: Minister of Health of the Republic of Indonesia; 2017 [cited at 2021 Apr 10]. Available from: https://web. persi.or.id/images/2017/pengurus-harian/implementasi_ehealth.pdf.

20. Seniwati E. Pcare BPJS Kesehatan untuk Faskes Pertama (Klinik, Puskesmas, Dokter) [Internet]. Jakarta, Indonesia: BPJS Kesehatan; 2019 [cited at 2021 Apr 10]. Available from: https://www.panduanbpjs.com/pcare-bpjsuntuk-faskes/.

21. Minister of Health of the Republic of Indonesia. Regulation of the Minister of Health of the Republic of Indonesia Number 19 of 2016 concerning an integrated emergency response system [Internet]. Jakarta, Indonesia: Minister of Health of the Republic of Indonesia; 2016 [cited at 2021 Apr 10]. Available from: https:// peraturan.go.id/peraturan/view.html?id=11e6b62f 8f2449608185313233303036.

22. Handayani PW, Saladdin IR, Pinem AA, Azzahro F, Hidayanto AN, Ayuningtyas D Health referral system user acceptance model in Indonesia. Heliyon 2018;4(12): $\mathrm{e} 01048$.

23. World Health Organization. Standards for improving quality of maternal and newborn care in health facilities [Internet]. Geneva, Switzerland: World Health Organization; 2016 [cited at 2021 Apr 10]. Available from: https://apps.who.int/iris/bitstream/handle/10665/ 249155/9789241511216-eng.pdf? sequence $=1$.

24. Sutiono AB, Qiantori A, Prasetio S, Santoso H, Suwa $\mathrm{H}$, et al. Designing an emergency medical information system for the early stages of disasters in developing countries: the human interface advantage, simplicity and efficiency. J Med Syst 2010;34(4):667-75.

25. Wahid F, Dirgahayu RT, Hamzah A, Setiaji H. When more is less: the case of disconnected information systems in Indonesian public health facilities. IOP Conf Ser Mater Sci Eng 2018;325:012017.

26. World Health Organization. Framework and standards for country health information systems. 2nd ed. Geneva, Switzerland: World Health Organization; 2008. 